\title{
ENVIRONMENTAL MODELLING OF FOREST VEGETATION ZONES AS A SUPPORT TOOL FOR SUSTAINABLE MANAGEMENT OF CENTRAL EUROPEAN SPRUCE FORESTS
}

\author{
IVO MACHAR $^{1 *}$, VERONIKA VLCKOVA ${ }^{2}$, LUBOMIR SALEK $^{3}$, VILEM PECHANEC ${ }^{4}$, \\ ARKADIUSZ NOWAK ${ }^{5}$, SYLWIA NOWAK $^{6}$, VITEZSLAV PLASEK $^{7}$, JURAJ SVAJDA $^{8}$, \\ ZDENEK OPRSAL ${ }^{9}$, OSMAN TOPACOGLU ${ }^{10}$ \\ 1, 4, 9 Faculty of Science, Palacky University, Olomouc, Czech Republic \\ ${ }^{2}$ Faculty of Transportation Sciences, Czech Technical University, Prague, Czech Republic \\ ${ }^{3}$ Faculty of Forestry and Wood Technology, Czech University of Life Science, Czech \\ Republic \\ ${ }^{5,6}$ Faculty of Natural Sciences and Technology, Opole University, Opole, Poland \\ ${ }^{7}$ Faculty of Science, Ostrava University, Ostrava, Czech Republic \\ ${ }^{8}$ Matej Bel University, Faculty of Science, Tajovskeho 40, 97401 Banska Bystrica, Slovak \\ Republic \\ ${ }^{10}$ Kastamonu University, Kastamonu, Turkey \\ *Corresponding author e-mail: ivo.machar@upol.cz
}

Received: $17^{\text {th }}$ May 2018, Accepted: $6^{\text {th }}$ December 2018

\begin{abstract}
The impact of climate change on forest ecosystems may manifest itself by a shift in forest vegetation zones in the landscape northward and into higher elevations. Studies of climate change-induced vegetation zone shifts in forest ecosystems have been relatively rare in the context of European temperate zone (apart from Alpine regions). The presented paper outlines the results of a biogeographic model of climatic conditions in forest vegetation zones applied in the Central European landscape. The objective of the study is a prediction of future silvicultural conditions for the Norway spruce (Picea abies L. Karst.), which is one of the principal tree species within European forests. The model is based on a general environmental dependence of forest vegetation zones on the long-term effect of altitudinal and exposure climates defined by the mean and extreme air temperatures and the amount and distribution of atmospheric precipitation. The climatological data for the model were provided by a validated regional climate database for 2010 - 2090 according to the SRES A1B scenario, bound to specific geo-referenced points in the landscape. The geobiocoenological data in the model were provided by the Biogeography Register database which contains ecological data on the landscape bound to individual cadastres of the entire Czech Republic. The biogeographic model applies special programs (the FORTRAN programming language) in the environment of geographic information systems. The model outputs can be clearly graphically visualized as scenarios of predicted future climatic conditions of landscape vegetation zones. Modelling of the regional scenario of changes in the climatic conditions of forest vegetation zones reveals that in the prediction period of 2070 and beyond, good and very good climatic conditions for the cultivation of forests with dominant Norway spruce will be found only in some parts of its today's native range in forest
\end{abstract}


Machar et al.: Environmental Modelling of Forest Vegetation Zones as a Support Tool for Sustainable Management of Central European Spruce Forests

vegetation zones $5-8$. Based on the results provided by the regional scenario, the authors of this paper recommend fundamental reassessment of the national strategy of sustainable forest management in the Czech Republic, stipulating that the current practice of spruce cultivation be reduced only to areas specifically defined by the biogeographic model. The paper shows that biogeographic models based on the concept of vegetation zoning can be applied not only in regional scenarios of climate change in the landscape but also as support tools for the creation of strategies of sustainable forest management.

Keywords: Adaptive management, biogeographic model, forest vegetation zones, regional scenario of changes in climatic conditions

\section{INTRODUCTION}

Over the last 100 years, increasing average global temperatures and changed precipitation rates have induced changes in vegetation zoning in ecosystems around the world (Gonzales et al,. 2010). Modelling of global vegetation changes using General Circulation Models (Grassl, 2000) provides a clear picture of global changes in the distribution of vegetation formations. However, it is known that estimates of changes in climate parameters differ significantly among various global climate models, particularly estimates for the nearest decades (Dubrovský et al., 2014). Moreover, global vegetation models cannot take individual plant species into consideration and their theoretical background therefore disregards the migration abilities of individual species as well as the vegetation succession processes at the level of specific ecosystems (Neilson et al., 2005). It is therefore most suitable to conduct regional-scale studies of the impact of climate change on species distribution and succession processes at the ecosystem level (Drégelyi-Kiss et al., 2008). Added to this, climate change often influences specific ecosystems in a specific geographic region in synergy with other specific regional impacts, such as landscape fragmentation (Opdam \& Wascher, 2004). Regional models of vegetation changes are therefore seen as one of the fundamental knowledge bases allowing us to understand the significance of climate change within specific target ecosystems (Walther, 2010).

In forest ecosystems, climate change impacts on a regional scale are most notably demonstrated by a shift in forest vegetation zones (vegetation zonation) towards higher elevations (Garamvoelgyi \& Hufnagel, 2013). Processes of disturbances and interspecific competition, as well as different phenotypic plasticity and different local adaptation of the dominant species of the given ecosystem introduce considerable uncertainties into regional models of forest vegetation zone shifts (Iverson \& McKenzie, 2013). Tree growth response to climate change manifests itself in long-term time scales (Büntgen et al., 2007). Currently, it is probably best documented by shifts in the upper forest limit in European mountain ranges (Švajda, 2008).

Understanding of the ongoing or potential vegetation zone shifts may be a key to the development of sustainable forest management strategies in the context of predicted climate change (Kulhavý, 2004). Vegetation zones represent the basic framework of climatic conditions for the cultivation of tree species in production forests (Svobodová \& Voženílek, 2010), which are dominant in the European temperate zone. However, the existing published studies on shifts in forest ecosystem vegetation zonation are limited to a few countries in the temperate climate zone of Europe, most of them concentrating on the Alpine region (Rosbakh et al., 2014). Outside the Alpine countries, Švajda et al. (2011) studied the altitudinal shift in dwarf pine vegetation at the upper forest limit in the High Tatra Mts. (Slovakia), while Kutnar \& Kobler (2011) published a prediction of climate-change induced 
changes in forest vegetation zones in Slovenia. Zajaczkowski et al. (2013) focused on predicting the climate change impact on forest tree species in Poland, while Treml \& Chuman (2015) studied the impacts of terrain and vegetation structure on the dynamics of forest ecotone limit in the context of climate changes in the Central European Sudeten mountain ranges.

This paper deals with applying of vegetation zonation to the modelling of future changes in the climatic conditions of the Norway spruce (Picea abies L. Karst.). Forests with naturally dominant Norway spruce (Svoboda et al., 2010) represent a prevailing type of potential natural vegetation of mountain vegetation zones in the European temperate zone (Bohn et al., 2002). However, the present distribution of Norway spruce in the cultural landscapes of Europe is not limited only to mountain vegetation zones, as it has been subject to intensive forest cultivation since the early $19^{\text {th }}$ century (Š́lek et al., 2013).

Climate changes in the past decades have increased the risk to pests and pathogens infestation of Norway spruce dominated forests (Santini et al., 2013; Jactel et al., 2012). Solutions are sought in adaptations of different strategies of Norway forest management (Keskitalo, 2011; Klenk et al., 2011), particularly focusing on the reduction of spruce monocultures and their replacement with mixed forests (Griess et al., 2012; Kharuk et al., 2015; Lasch-Born et al., 2015; Matthies \&Valsta, 2016). Neuner et al. (2015) proved that spruce in mixed forests is less threatened by climate change impacts than pure Norway spruce stands. Naturally, climate change impacts on Norway spruce in a local scale are modified by soil conditions, as was shown by Zubizarreta-Gerendiain et al. (2015) in a study from Finland.

The predicted drier and warmer climate will have a significant impact on Norway spruce on the edges of its natural distribution range (Oberhuber et al., 2015). The impact of drought increasing mortality of spruce stands is also expected in South European mountains, where Norway spruce is a native species of mountain forests (Panayotov et al., 2016). In the Czech Republic, the current spells of agricultural drought (Brázdil \& Trnka, 2015) result in large-scale dieback of spruce stands in lowlands and uplands. Modelling of changes in the climatic conditions of Norway spruce vegetation zones may therefore help formulate strategies of adaptive measures related to Norway spruce stands (Anonymous, 2014). This may prove crucial in the field of sustainable forest management (Parviainen \& Frank, 2003) based on the principles of adaptation approach to forest ecosystems (Idle, 2005).

This paper aims to assess the impact of predicted changes in the climatic conditions of forest vegetation zones in Central Europe on growth conditions of Norway spruce. Results of this scenario can be applied as a support tool for sustainable forest management in forests with dominant Norway spruce. There are still many uncertainties concerning predictions of regional impacts of climate change on European forests (Lindner et al., 2004) - therefore it is another goal of this study to draw attention to the somewhat neglected significance of the application of biogeographic models, arising in the concept of forest vegetation zones, within strategies of sustainable forest management (see chapter 2.2). The paper presents the results of applying the biogeographic model in the landscape of the Czech Republic for the prediction period $2030-2090$.

\section{MATERIAL AND METHODS}

\section{Principles of the biogeographic model}

The biogeographic model of climatic conditions in vegetation zones (hereinafter referred to as "model") in the Czech Republic (hereinafter "CR") is based on the relationship between the current regional climate and the distribution of forest vegetation zones in the landscape 
Machar et al.: Environmental Modelling of Forest Vegetation Zones as a Support Tool for Sustainable Management of Central European Spruce Forests

(Vlčková et al., 2015). The model draws on the assumption that the general ecological relationship between climatic conditions and forest vegetation zoning will be maintained in the future (Kirilenko \& Solomon, 1998; Yee \& Mitchell, 1991) and that the expected climate change will be manifested by changes in the climatic conditions in the existing forest vegetation zones at the regional level which can be predicted (Woodward et al., 1998). This does not imply that the existing vegetation zones will simply extend (shift) to higher elevations of the European cultural landscape. The model reveals scenarios of future predicted changes in climatic conditions of vegetation zoning. The main principle of the model is based on using of forest vegetation zones as a reference framework for climate predictions of growth (silvicultural) conditions for Norway spruce (Úradníček et al., 2001). As pointed Jirásek (1996), the current representation of Norway spruce in the CR forests is $53.1 \%$, which is significantly more than the natural representation of Norway spruce in potential natural vegetation (11.2\%).

\section{Model inputs}

The existing forest vegetation zones in the Czech Republic (see Tab. 1) were defined using the bio-indication method of the well-established work by Professor Zlatník (Zlatník, 1976) and their ecological characteristics are gradually refined (Buček \& Lacina, 2006). Detailed characteristics of the ecotope, natural state of ecosystems and the current state of the landscape in individual vegetation zones are included in the characteristics of the geobiocoenological landscape typology units of the Czech Republic (Buček \& Lacina, 2007) which translate well into European forestry, agricultural and nature conservation typology systems of habitats (e.g. the habitat typology used in the Natura 2000 network). Detailed climatological characteristics of individual vegetation zones in CR were adopted from papers by Vondráková et al. (2013) and Macků (2014).

Climatological data used by the model are providing by the predictive climate database of the Czech Hydrometeorological Institute (CHMI) called CLIDATA which assigns climate data to a set of 131 points regularly distributed throughout the territory of the Czech Republic in the form of a regular trapezoidal network. CLIDATA contains a large validated database of climate parameters calculated by the ALADIN-CLIMATE.CZ model for the period 2010 - 2090 (Pretel, 2009) for the SRES A1B scenario (Nakićenović \& Swart, 2000).

The Register of Biogeography (Machar, 2013), which contains a detailed geobiocoenological characteristics of the CR landscape (vegetation zoning, trophic and hydric series) matched with individual cadastral areas, provides biogeographic data for the model. The Register of Biogeography contains geobiocoenological characteristics for each of the approx. 13,000 cadastral areas (polygons covering an average area of $6 \mathrm{~km}^{2}$ ) fully covering the territory of the Czech Republic. The choice of cadastral areas as the basic spatial units used by the Register was motivated by the possibility to evaluate the dynamics of changes in the landscape using periodically updated databases from the Integrated System on the Territory which characterize the current state of and pressure on the landscape (particularly land use and number of inhabitants). These databases also use the cadastral areas as their basic spatial units. The possibility to create application programs utilizing up-to-date data on factors affecting the landscape was the key motivation for using cadastral areas as the basic elements of the Register of Biogeography. Naturally, the cadastral areas as historically conditioned units of territorial division for the purposes of property and land use records are not entirely homogenous from the perspective of local natural conditions (Lipský, 2000). However, on the regional scale (for the entire territory of CR) the cadastre polygons are quite representative of the heterogeneity of the entire country's natural conditions, since the original $19^{\text {th }}$ century cadastre system (which has not changed much since) used natural 
boundaries such as streams, forest edges or major geomorphological formations in the landscape (Skaloš \& Engstová, 2010).

\section{Data processing}

The biogeographic model of changes in climatic conditions of vegetation zones represents a suite of special programs (FORTRAN programming language) and GIS applications of Esri products. It is a static model which does not enable predictions of the rate of vegetation changes. Climate characteristics (i.e. individual climatological variables used) were assigned to the definition points of the Register of Biogeography using analytic geometry by recalculation of a regular trapezoidal network. This network of points with a fine resolution of $250 \mathrm{~m}$ with the values of climatic variables of their four closest neighbours in the original CLIDATA climatic database was calculated using the gradient method (Vlčková, 2014). The predicted climate characteristics of the definition points, their respective potential vegetation zones and corresponding characteristics of natural climatic conditions are algorithmized by the model. Algorithmization of climate growth and ecological conditions for Norway spruce in relation to vegetation zones is conducted using the method of spatio-temporal analogies, with Lang's Rain Factor used as the coefficient of relationship combining total annual precipitation and average annual temperature in a single value (Kupka, 2006). The algorithmization divides the climatic conditions for Norway spruce cultivation into a relative four-step scale: "completely unsuitable climatic conditions", "moderately suitable climatic conditions", "good climatic conditions" and "very good climatic conditions". The model outputs for defined conditions (climate scenario for a defined period, defined geographic area, and algorithmized ecological conditions of Norway spruce) provide a regional scenario of predicted future climatic conditions for Norway spruce cultivation.

\section{RESULTS}

\section{Regional scenario of changes in climatic conditions of vegetation zones of the Czech Republic}

The regional scenario of changes in climatic conditions of the vegetation zones of the Czech Republic for the prediction period 2030 - 2090 (hereinafter "the regional scenario") clearly indicates three major predicted trends (see Tab. 1): (i) a gradual increase in areas with climatic conditions of lower vegetation zones (i.e. zones $1-3$ ), (ii) an area with climatic conditions of vegetation zone 4 will be still dominant in the CR landscape in the future as well, and (iii) a significant and fast decline in areas with climatic conditions of higher vegetation zones $(5-8)$.

\section{Application of the regional scenario in sustainable management of forests with dominant Norway spruce}

According to the regional scenario, the climatic conditions for Norway spruce cultivation in CR will gradually deteriorate. At present, very good and good climatic conditions for spruce cultivation prevail in approximately two thirds of the country's territory (Tab. 2). A graphic visualization of the regional scenario in Fig. 1 reveals that spruce finds very good and good climatic conditions in upland to mountain regions of CR. Very good climatic conditions for spruce correlate with the currently defined vegetation zones $5-8$ in the mountain regions of the country (where Norway spruce has its growth optimum). Moderately suitable or completely unsuitable climatic conditions for spruce cultivation can be found in the lowland regions of CR. (Fig. 1). 


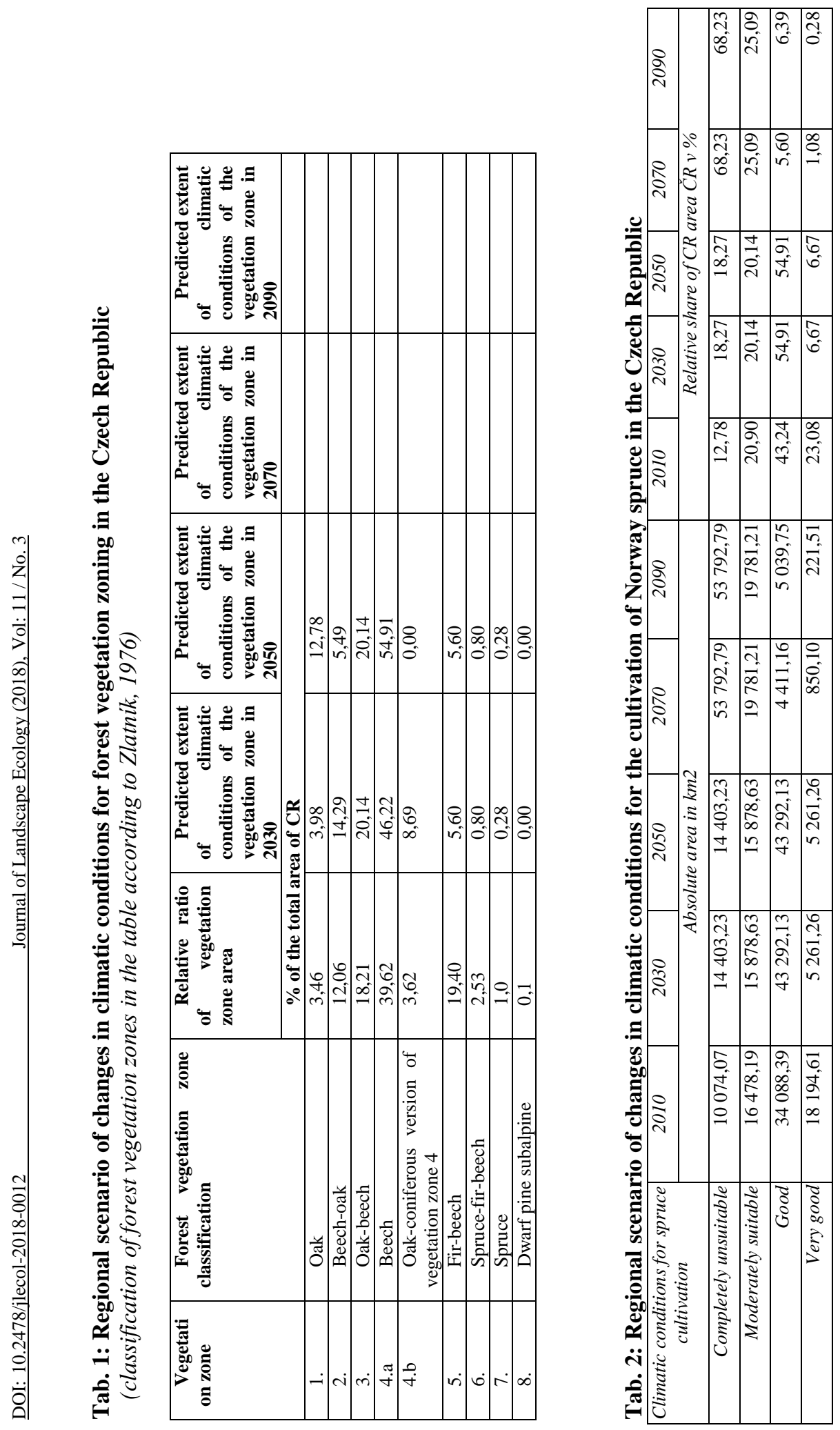




\section{Fig. 1: Present state of climatic conditions for Norway spruce cultivation in CR} (in 2010)

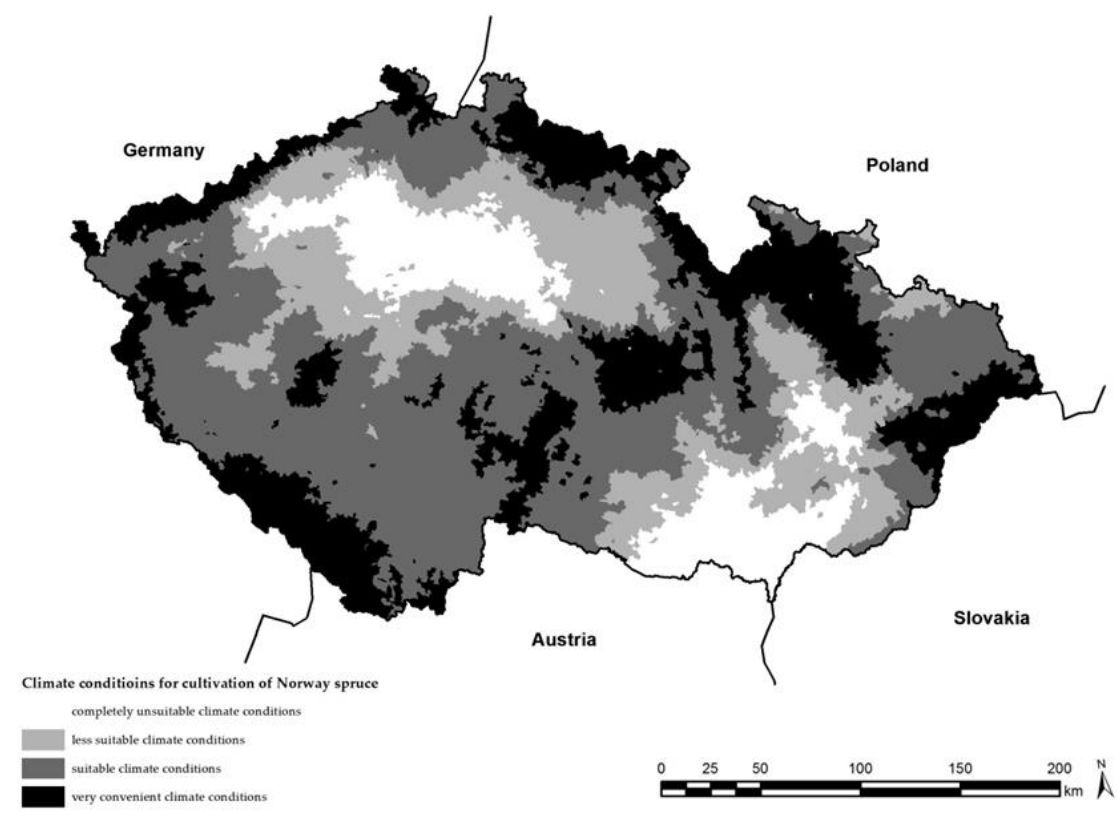

Compared with 2010, the regional scenario for 2030 reveals a significant decrease (by $16.41 \%$ ) in the area of very good climatic conditions for spruce cultivation (Tab. 2). A visualization of the regional scenario for 2030 (Fig. 2) clearly shows a loss in very good climatic conditions for Norway spruce in the vast upland regions of the central part of the country and at the foothills of the highest mountain ranges. In the prediction period of 2050, the trend of climatic conditions for Norway spruce will not be very pronounced (Tab. 2), and the situation according to the regional scenario will similar that in 2030 (Fig. 3).

According to the regional scenario, the ratio of sites with climatic conditions completely unsuitable for spruce cultivation will increase significantly in 2070 to $68.23 \%$ of the area of the Czech Republic (Tab. 2). The ratio of sites with good climatic conditions for spruce will drop to $5.60 \%$ in 2070 and the area of sites with very good climatic conditions will be reduced to a mere $1.08 \%$ (compared with the present state, this represents a loss of $22 \%$ ). This trend of changes in climatic conditions is clearly visible in the comparison of graphic visualizations of the regional scenario in Fig. 3 and Fig. 4: According to the scenario, in approximately 55 years very good and good climatic conditions for spruce cultivation on most of the territory of today's Czech Republic will be limited to small sites in the highest mountain regions (Šumava, Krkonoše Mts., Kralický Sněžník, Hrubý Jeseník Mts., Krušné Mts.). The scenario predicts that this trend will remain largely unchanged in the prediction period 2090 (Fig. 4). 
Machar et al.: Environmental Modelling of Forest Vegetation Zones as a Support Tool for Sustainable Management of Central European Spruce Forests

Fig. 2: Visualization of climatic conditions for Norway spruce cultivation in CR for prediction period of 2030

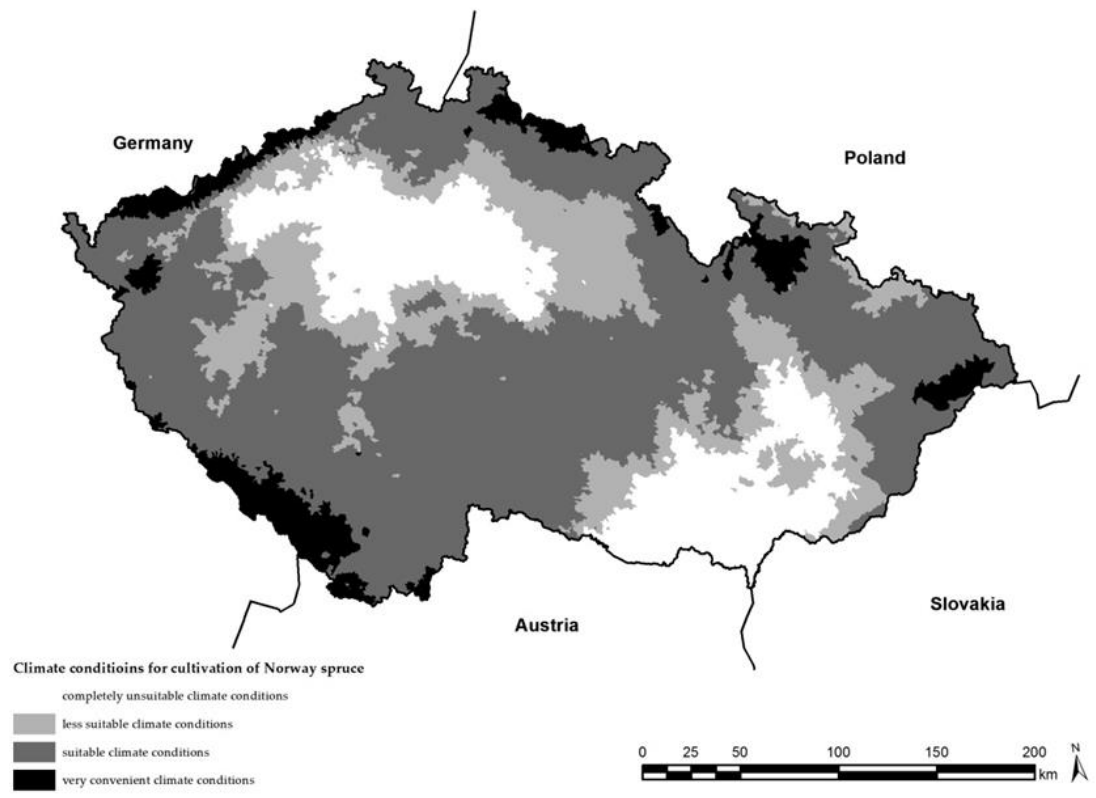

Fig. 3: Visualization of climatic conditions for Norway spruce cultivation in CR for prediction period of 2050

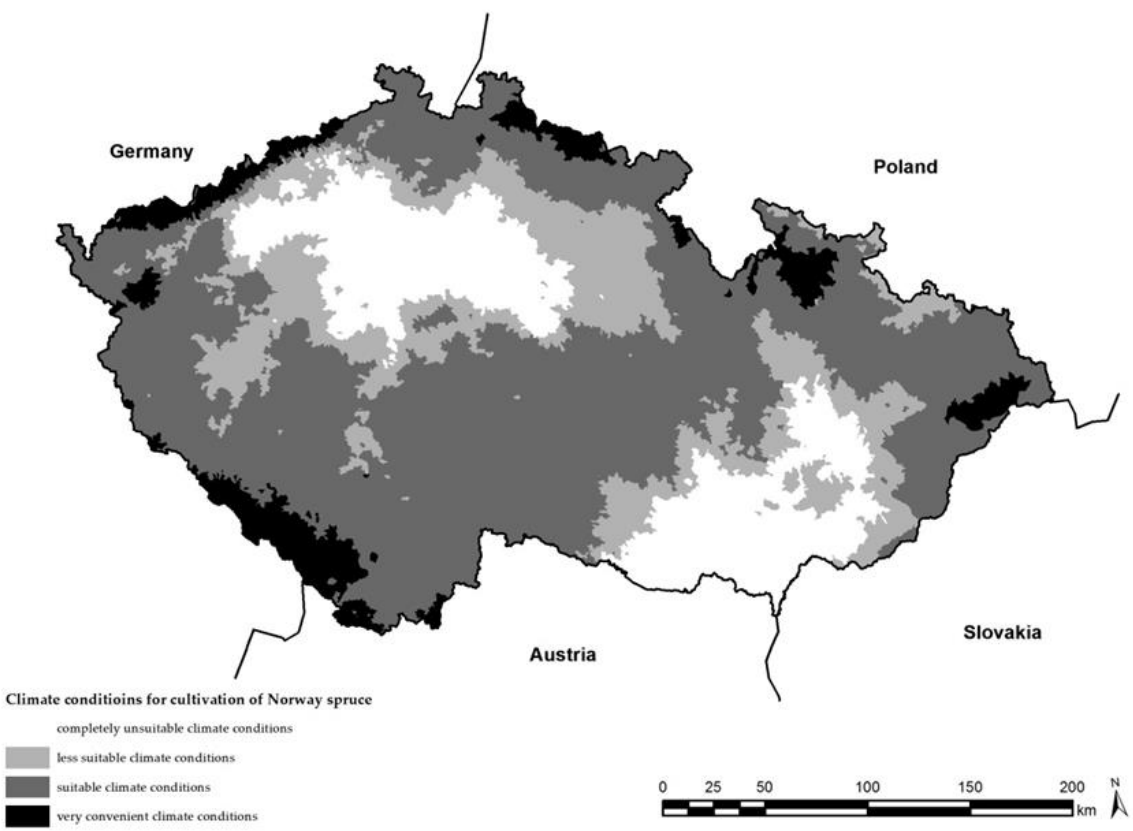


According to the regional scenario for 2070 , good and very good climatic conditions for the cultivation of forests with dominant Norway spruce will be found only in specific cadastral areas of the regions where natural range of spruce is common today, i.e. in vegetation zones $5-8$ (Fig. 4 and Fig. 5). Based on the results provided by the regional scenario, we recommend fundamentally reassessment of the Czech national strategy of sustainable forest management (National Forestry Program) in order to restrict the currently common practice of spruce cultivation only to areas defined precisely by the biogeographic model in the mountain regions of vegetation zones 5 to 8 . The strategy of sustainable spruce forest management in the Czech Republic should therefore contain a new premise (supported by state subsidy policy) that new man-made spruce plantations will no longer be established in forest vegetation zones 1 to 4 . According to the regional scenario for CR, spruce plantations newly established in regions with climatic conditions of today's forest vegetation zones 1 to 4 do not stand a chance of surviving until the felling age unless planted in suitable climatic conditions.

Fig. 4: Visualization of climatic conditions for Norway spruce cultivation in CR for prediction period of 2070

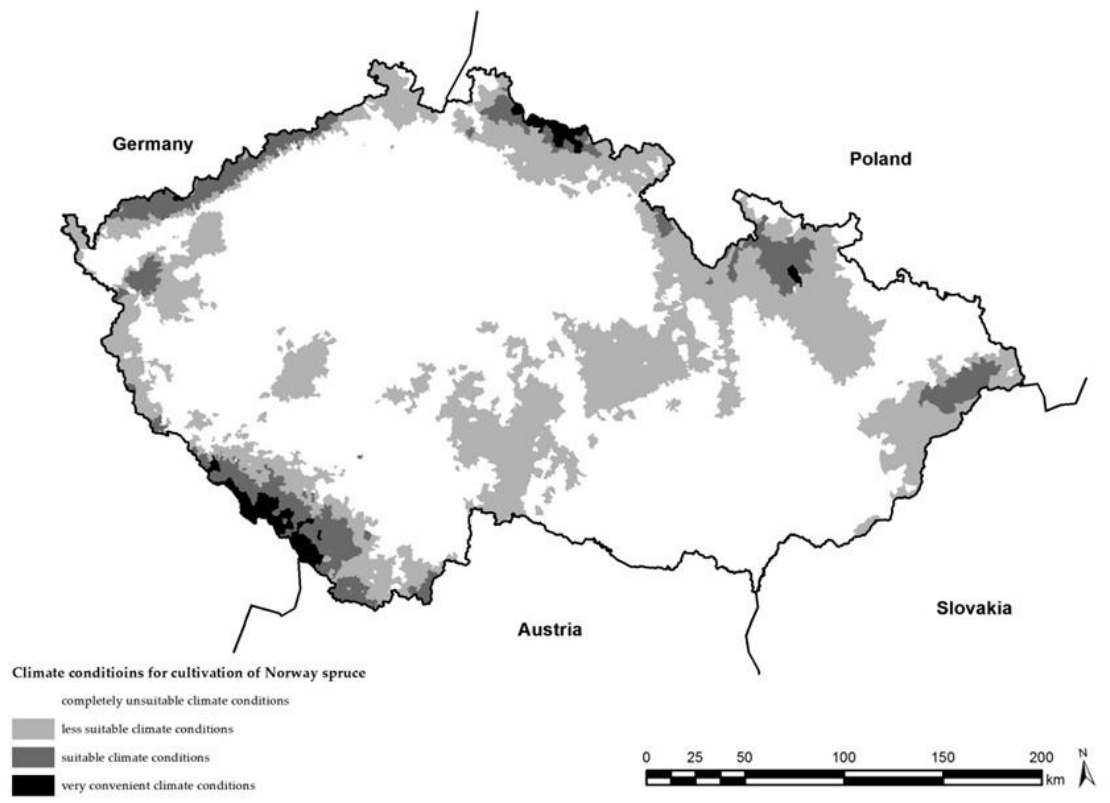


Fig. 5: Visualization of climatic conditions for Norway spruce cultivation in CR for prediction period of 2090

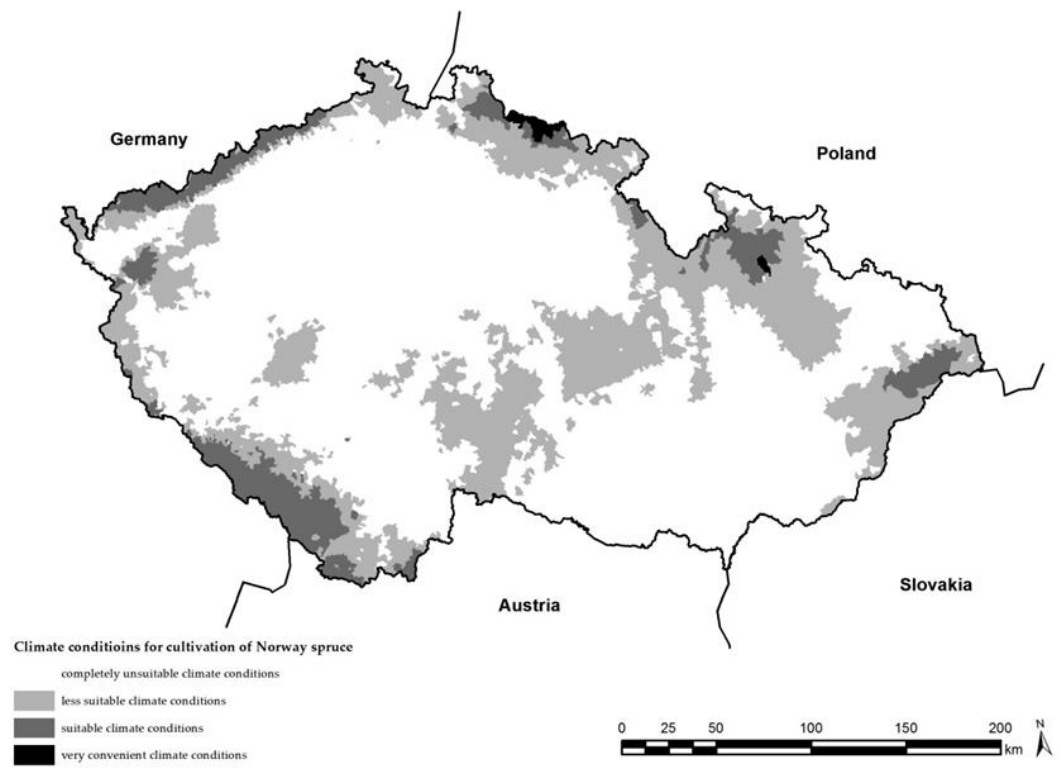

\section{DISCUSSION AND CONCLUSION}

Increasing average annual temperatures and more frequent occurrences of drought episodes have resulted in a significant threat to coniferous forests in Europe (Zang et al., 2014). According to Naudts et al. (2016), cultivation of spruce forests in Europe since 1750 has contributed to an increase of summer temperatures by $0.12{ }^{\circ} \mathrm{C}$ due to the fact that, unlike the open crowns of broadleaved trees, dark crowns of coniferous trees absorb the sun's heat.

The predicted change in climatic conditions for spruce cultivation in relation to forest vegetation zones as presented in this paper is consistent with the expected trends in vegetation changes induced by climate change in Europe under the EUROMOVE ecological model for European vegetation (Bakkenes et al., 2002). The main trends of the presented results are also in line with the currently observed trends of changing distribution of wild organisms which are attributed to climate change. Konvička et al. (2003), for example, observed that certain butterfly species expand their range to higher elevations of the Czech Republic, a fact which they explain by the impact of climate change. Reif et al. (2008) demonstrated that in the context of climate change the ongoing changes in bird populations and shifts in nesting sites within the country are due to the decline in species adapted to the colder climates of mountainous areas and the concurrent expansion of the ranges of lower elevation species. This in fact correlates with the presented regional scenario of changes in climatic conditions for spruce cultivation. The present upper forest limit in the highest mountain ranges of the Czech Republic is demonstrably shifting to higher elevations at the expense of forest-free habitats of alpine grasslands (Šenfelder \& Maděra, 2011). 
The Fifth Assessment Report for the Intergovernmental Panel on Climate Change (IPPC) defined a set of four new scenarios - the so-called Representative Concentration Pathways (RCP). Predicted regional climate data for CR under these scenarios are not yet available, which is why the biogeographic model in this paper applied the SRES A1B scenario based on a validated regional climate database. At present, one of the most important research projects modelling regional climate change and its impact on ecosystems is probably the CORDEX project (www.wcrp-cordex.ipsl.jussieu.fr), with its Europe-specific section called EURO-CORDEX (www.euro-cordex.net). Outputs of regional CORDEX modelling applicable in regional adaptation studies should be available in the $500 \times 500 \mathrm{~m}$ grid in the future.

Modelling of the spatial aspects of the occurrence, development and impacts of vegetation zones generates material for further research activities (Tuček et al., 2013). Jiménez-Alfaro et al. (2014) studied the impacts of elevation and land surface on different species of biogeographic groups of alpine plant communities by modelling on a $15 \times 15 \mathrm{~m}$ grid in the territory of Picos de Europa in Spain. Elevation was the key variable affecting the overall floristic diversity of the community - a conclusion which supports hypotheses on the relation between altitudinal climate and vegetation belts. However, the occurrence of individual species was more influenced by the slope aspect, topographic index, soil water content and sun radiation than by elevation alone. The existing models of future distribution of flora and fauna tend to focus on individual target species or species groups (Parmesan, 2005). Living organisms engage in the ecosystem processes within their ecological niches and thus the response of biota to climate change is more likely to be identified at the level of ecosystem diversity. The biogeographic regional models are particularly useful in this respect (Lomolino et al., 2005).

A vast majority of the biogeographic models encompasses correlational models based on the interdependence of given environmental bioclimatic variables (most commonly average temperature and average precipitation). These models also deal with the present range of a species, or characteristics of the given species' ecological niche (Peterson et al., 1999). If, based on the climate scenarios, it is predicted how the climate may change in the future, corresponding biological species or their communities with zonal distribution are assigned to the changed variables - in the model applied in this paper this involves vegetation zones and algorithmization of climatic requirements of spruce. This procedure is commonly referred to as bioclimatic envelope modelling (Botkin, 2007). The biogeographic model of changes in climatic conditions for Norway spruce cultivation due to predicted climate change used in this study is a representative of biogeographic processing models, a group of models used for predicting equilibrium responses of vegetation to potential climate change on a regional level (for more detailed information see e.g. Peterson et al., 2005). This type of models identifies environmental restrictions in relation to the distribution of plant formations (vegetation zones) under various equilibrium climatic conditions (Giorgi et al., 2002). The biogeographic model applied in this study uses the dependence of vegetation zones on long-term effects of the altitudinal and exposure climates defined by both the average and extreme air temperatures and the amount and distribution of atmospheric precipitation (Vahalík \& Mikita, 2011). The classification of the present forest vegetation zones on the territory of the Czech Republic (Mackovčin, 2000) is specified within the Czech Forest Ecosystem Classification (Viewegh et al., 2003), which in turn constitutes the groundwork for forest cultivation on ecological principles (Průša, 2001).

The predicted trend of changes in climatic conditions of forest vegetation zones will bring about a significant deterioration in the cultivation conditions of the commercial tree species in today's forest management in the Czech Republic. The still prevailing focus of forest 
Machar et al.: Environmental Modelling of Forest Vegetation Zones as a Support Tool for Sustainable Management of Central European Spruce Forests

management on the cultivation of Norway spruce monocultures in lowland and upland regions of the country will not be viable in 2050 anymore. Seen in the context of this scenario, planting of Norway spruce in production forests which in 2050 will be situated in vegetation zones 1, 2 and 3 appears to be both environmentally and economically inefficient. The scenario suggests that sustainable forest management strategies in lowland and upland regions of CR should focus on system changes as to the target tree species composition of production forests and should favour economically less profitable but more ecologically suitable native broadleaved species of the corresponding vegetation zones (see vegetation zone descriptions in Tab. 1).

The predicted shift in good and very good climatic conditions for Norway spruce towards the highest mountain ridges will most probably have a significant impact on the present biodiversity of the unique ecosystems of alpine grasslands. Climate change is likely to induce the shift of alpine timberline ecotone to higher altitudes in favour of expanding high-elevation spruce forests. According to the regional scenario, this trend will be evident as early as 2030. Mitigation measures aimed at maintaining alpine grasslands in highest mountain elevations of CR (Hrubý Jeseník Mts., Kralický Sněžník, Krkonoše Mts.) should therefore focus on downsizing the plantations of non-native dwarf pine which was introduced into alpine grasslands in the early $20^{\text {th }}$ century and which is a highly competitive species for Norway spruce in these high-elevation environmental conditions.

Vegetation redistribution simulations by biogeographic models represent a static (equilibrium) perspective of the analysed issue. Static/equilibrium biogeographic models thus provide useful "pictures" of terrestrial ecosystems in equilibrium with particular climatic conditions at a given time (Neilson et al., 1998). Yet, application of these models is limited, as they fail to simulate all the known internal factors of vegetation dynamics, such as interspecies competition, natality and mortality of populations or physiological factors. To overcome such limitations, the so-called dynamic global vegetation models (Prentice \& Webb, 1989) have been developed to integrate vegetation dynamics and ecosystem functions. However, many of them are not applicable on a regional scale as yet (Bachelet et al., 2001). Species-specific models have been capable of partially eliminating some uncertainties inherent in the prediction models due to insufficiently detailed data on the autecology of particular species. But such models are rare and tend to be applicable on the continental scale, which can provide only rough guidelines for regional applications (Morin $\&$ Thuiller, 2009). When interpreting mathematic models of the impact of climate change on biota, it is therefore necessary to always take into consideration that the models cannot be taken as accurate predictions of future developments (Ackerman et al., 2009). Models may significantly enhance predictions thanks to their sophisticated analyses (by providing synthetic scenarios), yet their sensitive interpretations must be based on profound knowledge of the biology and ecology of the organisms which are being modelled (Walther et al., 2002).

An important asset of biogeographic models is their possible application within strategies of adaptation and mitigation measures in the landscape in the context of ecosystem services (Schröter et al., 2005). Vegetation zones serve as important frameworks of ecological conditions for the cultivation of agricultural crops and forest tree species. E.g. grapevine has best conditions in regions with climatic conditions of forest vegetation zone 1 and Norway spruce finds optimal growth conditions in forest vegetation zones $5-7$. A biogeographic model allows us to implement specific crops or tree species within the predicted shift of vegetation zones, provided that their growth conditions in relation to vegetation zoning are clearly defined. A study by Kopecká et al. (2013) demonstrated the practical applicability of such biogeographic model in the creation of a scenario of the climate change impact on the 
future growth conditions of sugar beet (Beta vulgaris altissima) in beet and corn-producing regions of Bohemia.

The first study to analyse both the continual fluctuation of agroclimatic conditions in the past 200 years and the expected shifts in the upcoming decades in the Central European region (Trnka et al., 2011) demonstrated an expansion of warmer and drier agroclimatic conditions in the most fertile agricultural regions. This study indicated that the development of European climate may result in the most massive shift in agroclimatic conditions since the onset of farming, which is beyond our historical experience. The same holds true for forestry (Kongsager et al., 2016; Pretel, 2011). Most authors therefore agree that in forestry the results of climate change predictions as well as analyses of their impacts on forest ecosystems need to be seen as limiting inputs when formulating sustainable forest management strategies (Campioli et al., 2012) which focus on conversions of coniferous monocultures into deciduous and mixed forests (Pretzsch et al., 2015). Based on results obtained through modelling, the presented paper recommends that strategies of sustainable forest management in the Czech Republic radically reduce the common practice of spruce management only to regions of its present natural biogeographical range in mountain regions in forest vegetation zones 5 to 8 .

\section{ACKNOWLEDGEMENTS}

The study was supported by a joint grant of Mendel University in Brno and Palacky University in Olomouc called "Platform for Systems Biology and Ecology of Tree Species" No. CZ1.07/2.4.00/17.0023, funded by ty State Budget of the Czech Republic and European Union funds. The authors would like to thank Ms. Táňa Vybíralová for the English translation. They would also like to express their gratitude to the anonymous reviewers for their comments and recommendations for the paper manuscript. This study is dedicated to the memory of Czech ecologist Antonín Buček (1942 - 2018).

\section{REFERENCES}

Ackerman, F., De Canio, S. J., Howarth, R. B., Sheeran, K. (2009). Limitations of integrated assessment models of climate change. Climatic Change, 95, č. 3-4, s. 297-315.

Anonymous (2014). Strategie přizpůsobení se změně klimatu v podmínkách $\check{C} R$. Ministry of Environment of the Czech republic, Prague.

Bachelet, D. R., Neilson, R. P., Lenihan, J. M., Drapek, R. J. (2001). Climate change effects on vegetation distribution and carbon budget in the U. S. Ecosystems, 4, s. 164-185.

Bakkenes, M., Alkemade, R.M., Ihle, F., Leemans, R., Latour, J.B. (2002). Assessing effects of forecasted climate change on the diversity and distribution of European higher plants for 2050. Global Change Biology 8: 390-407

Botkin, D. B. (2007). Forecasting the effects of global warming on biodiversity. BioScience, 57, s. 227-236.

Brázdil, R., Trnka, M. eds. (2015). Historie počasí a podnebí v českých zemích XI: Sucho v českých zemích: minulost, současnost a budoucnost. Centrum výzkumu globální změny Akademie věd České republiky, v.v.i., Brno, 402 s.

Buček, A., Lacina, J. (2006). Biogeografická diferenciace v geobiocenologickém pojetí a její využití v krajinném plánování. In: Dreslerová, J., Packová, P. (eds.): Ekologie krajiny a krajinné plánování (s. 18-29). Lesnická práce, Kostelec nad Černými lesy. 
Machar et al.: Environmental Modelling of Forest Vegetation Zones as a Support Tool for Sustainable Management of Central European Spruce Forests

Buček, A., Lacina, J. (2007). Geobiocenologie II. Geobiocenologická typologie krajiny České republiky. Mendelova zemědělská a lesnická univerzita Brno, 244 s.

Büntgen, U., Frank, D.C., Kaczka, R.J., Verstege, A., Zwijacz-Kozica, T., Esper, J. (2007). Growth responses to climate in a multi-species tree-ring network in the Western Carpathian Tatra Mountains. Tree Physiology, 27, s. 689-702.

Campioli, M., Vincke, C., Jonard, M., Kint, V., Demarée, G., Ponette, G. (2012). Current status and predicted impact of climate change on forest production and biogeochemistry in the temperate oceanic European zone: review and prospects for Belgium as a case study. Journal of Forest Research, 17: 1-18.

Drégelyi-Kiss, Á., Drégelyi-Kiss, G., Hufnagel, L. (2008). Ecosystems as climate controllers - biotic feedbacks. Applied Ecology and Environmental Research, 6, č. 2, s. 11-134.

Dubrovský, M., Hayes, M., Pierpaolo, D., Trnk,a M., Svoboda, M., Pierpaolo, Z. (2014). Multi-GCM projections of future drought and climate variability indicators for the Mediterranean region. Regional Environmental Change 14: 1907-1919.

Garamvoelgyi, A., Hufnagel, L. (2013). Impacts f climate change on vegetation distribution no.1. Climate change induced vegetation shifts in the Palearctic region. Applied Ecology and Environmental Research, 11, č. 1, s. 79-122.

Giorgi, F., Hewitson, B., Christensen, J., Hulme, M., Von Storch, H., Whetton, P., Jones, R., Merns, I., Fu, C. (2002). Regional climate information - Evaluation and projection. In: Houghton, J. T., Ding, Y., Griggs, D. J., Noguer, M., Van der Linden, P., Dai, X., Maskell, K., Johnson, C. I. (eds.): Climate Change 2001: The Scientific Basis (s. 583-638). Cambridge Univ. Press, New York.

Gonzales, P., Neilson, R. P., Lenihan, J. M., Drapek, R. J. (2010). Global patterns in the vulnerability of ecosystems to vegetation shift due to climate change. Global Ecology \& Biogeography, 19, s. 755-768.

Grassl, H. (2000). Status and improvements of coupled general circulation models. Science, 288, s. 1991-1997.

Griess, V.C., Acevedo, R., Härtl, F., Staupendahl, K., Knoke, T. (2012). Does mixing tree species enhance stand resistance against natural hazards? A case study for spruce. Forest Ecology and Management 267: 284-296.

Iverson, L.R., Mckenzie D. (2013). Tree-species range shifts in a changing climate: detecting, modelling, assisting. Landscape Ecology, 28, s. 879-889.

Jactel, H., Petit, J., Desprez-Loustau, M.L., Delzon, S., Piou, D., Battisti, A., Koricheva, J. (2012). Drought effects on damage by forest insects and pathogens: a meta-analysis. Global Change Biology 18: 267-276

Jiménez-Alfaro, B., Marcenó, C., Bueno, A., Gavilán, R., Obeso, J. R. (2014). Biogeographic deconstruction of alpine plant communities along altitudinal and topographic gradients. Journal of Vegetation Science, 25, s. 1, s. 160-171.

Jirásek, J. (1996). Společenstva přirozených smrčin České republiky. Preslia 67: 225-259.

Jönsson, A.M., Lagergren, F., Smith, B. (2015). Forest management facing climate change an ecosystem model analysis of adaptation strategies. Mitigation and Adaptation Strategies for Global Change 20: 201-220

Keskitalo, E.C.H. (2011). How can forest management adapt to climate change? Possibilities in different forestry systems. Forests 2:415-430 
Kharuk, V.I., Im, S.T., Dvinskaya, M.L., Golukov, A.S., Ranson, K.J. (2015). Climate-induced mortality of spruce stands in Belarus. Environmental Research Letters 10: 125006.

Kirilenko, A. P., Solomon, A. M. (1998). Modelling dynamic vegetation response to rapid climate change using bioclimatic classification. Climatic Change, 38, s. 15-49.

Klenk, N.L., Adams, B.W., Bull, G.Q., Innes, J.L., Cohen, S.J., Larson, B.C. (2011). Climate change adaptation and sustainable forest management: A proposed reflexive research agenda. Forest Chronicle 87:351-357

Kongsager, R., Locatelli, B., Chazarin, F. (2016). Addressing Climate Change Mitigation and Adptation Together: A Global Assessment of Agriculture and Forestry Projects. Environmental Management 57: 271-282.

Konvička, M., Maradová, M., Beneš, J., Fric, Z., Kepka, P. (2003). Uphill shifts in distribution of butterflies in the Czech Republic: effects of changing climate detected on a regional scale. Global Ecological Biogegraphy, 12, s. 403-410.

Kopecká, V., Machar, I., Buček, A., Kopecký, A. (2013). The Impact of Climate Changes on Sugar Beet Growing Conditions in the Czech Republic. Listy cukrovarnické a řepařské, 129, č. 11, s. 326-329.

Kulhavý, J. (2004). A new concept in sustainable forest management - the need for forest ecosystem and landscape research. Journal of Forest Science, 50(11): 520-525.

Kupka, I. (2006). Is the Lang's rain factor usable for assessing the microclimate influence on growth height of forest culture? Reports of Forestry Research, 51(3): 153-156.

Kutnar, L., Kobler, A. (2011). Prediction of forest vegetation shift due to different climate-change scenarios in Slovenia. Sumarski List, 135, č. 3-4, s. 113-126.

Lasch-Born, P., Suckow, F., Gutsch, M., Reyer, Ch., Hauf, Y., Murawski, A., Pilz, T. (2015). Forests under climate change: potential risks and Opportunities. Meteorologische Zeitschrift 24: $157-172$

Lindner, M., Fitzgerald, J.B., Zimmermann, N.E., Reyer, Ch., Delzon, S., van der Maaten, E., Schelhaas, M.J., Lasch, P., Eggers, J., van der Maaten-Theunissen, M., Suckow, F., Psomas, A., Poulter, B., Hanewinkel, M. (2014). Climate change and European forests: What do we know, what are the uncertainties, and what are the implications for forest management? Journal of Environmental Management 146: 69-83.

Lipský, Z. (2000). Sledování změn v kulturní krajině. Česká zemědělská univerzita v nakladatelství a vydavatelství Lesnická práce, s. r. o., Kostelec nad Černými lesy, 71 s.

Lomolino, M. V., Riddle, B. R., Brown, J. H. (2005). Biogeography. 3rd edition. Sinauer Assoc. Inc., Sunderland, $752 \mathrm{s.}$

Mackovčin, P. (2000). A multi-level ecological network in the Czech Republic: Implementing the territorial system of ecological stability. GeoJournal, 51, č. 3, s. 211-220.

Machar, I. (2013). Applying of the Biogeography Register to Predicting the Consequences of Global Climate Changes on the Landscape in the Czech Republic. In: Proceedings of the $11^{\text {th }}$ Int. Conference on Environment, Ecosystems and Development (p. 15-18). Brasov, Romania. Macků, J. (2014). Climatic characteristics of forest vegetation zones of the Czech Republic. Journal of Landscape Ecology (Brno), 7, č. 3, s. 39-48.

Málek, J. (1984). Dubojehličnatý vegetační stupeň v ČR. Zprávy Geografického stavu ČASV v Brně, 21(4): 35-54.

Matthies, B.D., Valsta, L.T. (2016). Optimal forest species mixture with carbon storage and 
Machar et al.: Environmental Modelling of Forest Vegetation Zones as a Support Tool for Sustainable Management of Central European Spruce Forests

albedo effect for climate change mitigation. Ecological Economics 123: 95-105.

Mermet, L., Farcy, C. (2011). Contexts and concepts of forest planning in a diverse and contradictory world. Forest Policy Economics 13:361-365

Morin, X., Thuiler, W. (2009). Comparing niche- and process-based models to reduce prediction uncertainty in species range shifts under climate change. Ecology, 90, č.5., s. 1301-1313.

Nakićenović, N., Swart, R. (2000). Special Report on Emissions Scenarios. A Special Report of Working Group III of the IPCC. Cambridge Univ. Press, New York. 612 s.

Naudts, K., Chen, Y., McGrath, M.J., Ryder, J., Valade, A., Otto, J., Luyssaert, S., (2016). Europe's forest management did not mitigate climate warming. Science 351, 6273: 597-599.

Neilson, R. P., Pitelka, L. F., Solomon, A. M., Nathan, R., Midgley, G. F., Fragoso, J. M. V., Lishke, H., Thompson, K. (2005). Forecasting Regional to Global Plant Migration in Response to Climate Change. Bioscience, 55, č. 9, s. 749-759.

Neilson, R. P., Prentice, I. C., Smith, B. (1998). Simulated changes in vegetation distribution under global warning. In: Watson, R. T., Zinyowera, M.C., Moss, R. H., Dokken, D. J. (eds): The Regional Impacts of Climate Change: An assessment of Vulnerability (p. 439-456). Cambridge Univ. Press.

Neuner, S., Albrecht, A., Cullmann, D., Engels, , F., Griess, V.C., Hahn, A., Hanewinkel, M., Härtl, F., Kölling, CH., Kaistaupendahl, Knoke, T. (2015). Survival of Norway spruce remains higher in mixed stands under a dryer and warmer climate. Global Change Biology 21: 935-946.

Oberhuber, W., Hammerle, A., Kofler, W. (2015). Tree water status and growth of saplings and mature Norway spruce (Picea abies) at a dry distribution limit. Frontiers in Plant Science 6: 703

Olesen, J.E., Trnka, M., Kersebaum, K.C., Skjelvag, A.O., Seguin, B., Peltonen-Sainio, P., Rossi, F., Kozyra, J., Micale, F. (2011). Impacts and adaptation of European crop production systems to climate change. European Journal of Agronomy, 34, s. 96-112.

Opdam, P., Wascher, D. (2004). Climate change meets habitat fragmentation: linking landscape and biogeographical scale levels in research and conservation. Biological Conservation, 117, s. 285-297.

Panayotov, M., Kuakowski, D., Tsvetanov, N., Krumm, F., Barbeito, I, Bebi, P. (2016). Climate extremes during high competition contribute to mortality in unmanaged self-thinning Norway spruce stands in Bulgaria. Forest Ecology and Management 369: 74-88 Parmesan, C. (2005). Biotic Response: Range and Abundance Changes. In: Lovejoy, T.E., Hannah, L. (eds.) Climate change and Biodiversity (p. 41-55). Yale Univ. Press, New Haven and London.

Peterson, A. T., Soberon, T. J., Sanchez-Cordero, V. (1999). Conservatism of ecological niches in evolutionary time. Science, 285, s. 1265-1267.

Peterson, A. T., Tian, H., Martínez-Meyer, E., Soberón, J., Sánchez-Cordero, V., Huntley, B. (2005). Modelling Distributional Shifts of Individual Species and Biomes. In: Lovejoy, T.E., Hannah, L. (eds.) Climate change and Biodiversity (pp. 211-228). Yale Univ. Press, New Haven and London.

Prentice, I.C., Webb, N.R. (1989). Developing a global vegetation dynamics model: Results of an IIASA, RR-89-7. Institute for Applied Systems Analysis, Laxenburg, Austria. 
Pretel, J. (2009). Současný vývoj klimatu a jeho výhled. Ochrana přirody, suppl., 46, s. 2-7. Pretel, J., ed. (2011). Zpřesnění dosavadních odhadi̊ dopadi̊ klimatické změny v sektorech vodního hospodářství, zemédělství a lesnictví a návrhy adaptačních opatření $(V)$ - Závěrečná zpráva o řešení 2007-2011, Projekt VaV - SP/1a6/108/07. ČHMÚ, Praha. 126 s.

Pretzsch, H., Biber, P., Uhl, E., Dauber, E. (2015). Long-term stand dynamics of managed spruce-fir-beech mountain forests in Central Europe: structure, productivity and regeneration success. Forestry 88: 407-428.

Průša, E. (2001). Pěstování lesư na typologických základech. Lesnická práce, s. r. o.

Reif, J., Storch, D., Voříšek, P., Št’astný, K., Bejček, V. (2008). Bird-habitat associations predict population trends in central European forest and farmland birds. Biodiversity Conservation, 17, s. 3307-3319.

Rosbakh, S., Bernhardt-Römermann, M., Poschlod, P. (2014). Elevation matters: contrasting effects of climate change on the vegetation development at different elevations in the Bavarian Alps. Alpine Botany, 124, č. 2, s. 143-154.

Santini, A., Ghelardini, L., De Pace, C., Desprez-Loustau, M.L., Capretti, P., Chandelier, A., Cech, T., Chira, D., Diamandis, S., Gaitniekis, T., Hantula, J., Holdenrieder, O., Jankovsky, L., Jung, T., Jurc, D., Kirisits, T., Kunca, A., Lygis, V., Malecka, M., Marcais, B., Schmitz, S., Schumacher, J., Solheim, H., Solla, A., Szabo, I., Tsopelas, P., Vannini, A., Vettraino, A.M., Webber, J., Woodward, S., Stenlid, J. (2013). Biogeographical patterns and determinants of invasion by forest pathogens in Europe. New Phytologist, 197(1): 238-250.

Schröter, D., Cramer, W., Leemans, R., Prentice, I. C., Araújo, M. B. (2005). Ecosystem service supply and vulnerability to global change in Europe. Science, 310, s. 1333-1337.

Skaloš, J., Engstová, B. (2010). Methodology for mapping non-forest wood elements using historic cadastral maps and aerial photographs as a basis for management. Journal of Environmental Management, 91, s. 831-843.

Skrøppa, T. (2003). EUFORGEN Technical Guidelines for genetic conservation and use for Norway spruce (Picea abies). International Plant Genetic Resources Institute, Rome, Italy. $6 \mathrm{pp}$.

Sturrock, R.N., Frankel, S.J., Brown, A.V., Hennon, P.E., Kliejunas, J.T., Lewis, K.J., Worrall, J.J., Woods, A.J. (2011). Climate change and forest diseases. Plant Pathology 60:133-149

Subramanian, N., Bergh, J., Johansson, U., Nilsson, U. (2016). Adaptation of Forest Management Regimes in Southern Sweden to Increased Risks Associated with Climate Change. Forests 7, 8.

Svobodová, J., Voženílek, V. (2010). Relief for Models of Natural Phenomena. In: Anděl, J., Bičík, I., Dostál, P., Shasneshin, S. (eds.): Landscape Modelling: Geographical Space, Transformation and Future Scenarios (Urban and Landscape Perspectives) (pp. 183-196). Springer, Dordrecht.

Šálek, L., Marušák, R., Tipmann, L, Turečková, M. (2013). Autochthonous Norway spruce outside mountain regions in the Czech Republic. Scientia Agriculturae Bohemica, 44, 151158.

Šenfelder, M, Maděra, P. (2011). Population Structure and Reproductive strategy of Norway spruce (Picea abies L. Karst) above the Former Pastoral Timberline in the Hruby Jesenik Mountains, Czech Republic. Mountain Research and Development 31(2): 131-143.

Švajda, J. (2008). Climate change and timber line in the European mountains - current 
Machar et al.: Environmental Modelling of Forest Vegetation Zones as a Support Tool for Sustainable Management of Central European Spruce Forests

knowledge and perspectives. Oecologia Montana, 17, s. 30-33.

Švajda, J., Solar, J., Janiga, M., Buliak, M. (2011). Dwarf Pine (Pinus mugo) and selected abiotic habitat conditions in the Western Tatra Mountains. Mountain Research and Development, 31, č. 3, s. 220-228.

Treml, V., Chuman, T. (2015). Ecotonal Dynamics of the Altitudinal Forest Limit are Affected by Terrain and Vegetation Structure Variables: An Example from the Sudetes Mountains in Central Europe. Arctic, Antarctic, and Alpine Research, 47, č. 1, s. 133-146.

Trnka, M., Brázdil, R., Dubrovský, M., Semerádová, D., Štěpánek, P., Dobrovolný, P., Možný, M., Eitzinger, J., Málek, J., Formayer, H., Balek, J., Žalud, Z. (2011). A 200-year climate record in Central Europe: implications for agriculture. Agronomy for Sustainable Environment, 31, č. 4, s. 631-641.

Tuček, P., Caha, J., Janoška, Z., Vondráková, A., Samec, P., Voženílek, V., Bojko, J. (2013). Forest vulnerability zones in the Czech Republic. Journal of Maps, 10, č. 1, s. 179-182.

Úradníček, L., Maděra, P., Kolibáčová, S., Koblížek, J., Šefl, J. (2001). Dřeviny české republiky. Matice Lesnická s.r.o. Písek.

Vahalík, P., Mikita, T. (2011). Possibilities of forest altitudinal vegetation zones modelling by geoinformatic analysis. Journal of Landscape Ecology (Czech Republic), 4, č. 2, s. 49-61.

Viewegh, J., Kusbach, A., Mikeska, M. (2003). Czech forest ecosystem classification. Journal of Forest Science 49: 85-93.

Vlčková, V. (2014). Systémový charakter modelování možných trendů důsledků klimatických změn nástroji geografických informačních systémů. Acta Informatica Pragensia, 3, č. 1, s. 70-88.

Vlčková, V., Buček, A., Machar, I., Daněk, T., Pechanec, V., Brus, J., Kiliánová, H. (2015). The application of geobiocoenological landscape typology in the modelling of climate change implications. Journal of Landscape Ecology (Czech Republic), 8, č. 2, s. 69-81.

Vondráková, A., Vávra, A., Voženilek, V. (2013). Climatic regions of the Czech Republic. Journal of Maps, 9, č. 3, s. 425-430.

Walther, G.R. (2010). Community and ecosystem responses to recent climate change. Philosophical transactions of the Royal society B - Biological Sciences, 365 (1549), s. 2019-2024.

Walther, G. R., Post, E., Convey, P., Menzel, A., Parmesan, C., Beebee, T. J. C., Fromentin, J. M., Hoegh-Guldberg, O., Fairlein, F. (2002). Ecological responses to recent climate change. Nature, 416, s. 389-395.

Woodward, F. I., Lomas, M. R., Betts, R. A. (1998). Vegetation-climate feedback in a greenhouse world. Philosophical Transactions of the Royal Society of London, B Biological Sciences, 353 (1356), s. 38-39.

Yee, T. W., Mitchell, N. D. (1991). Generalized additive models in plant ecology. Journal of Vegetation Sciences, 2, s. 587-602.

Zajaczkowski, J., Brzeziecki, B., Perzanowski, K., Kozak, I. (2013). Wplyw potencjalnych zmian klimatycznych na zdolność konkurencyjna glównych gatunków drzew w Polsce. Sylwan, 157, č. 4, s. 253-261.

Zang C., Hartl-Meier C., Dittmar C., Rothe A., Menzel A. (2014). Patterns of drought tolerance in major European temperate forest trees: climatic drivers and levels of variability. Global Change Biology, 20, 12: 3767-3779. 
Zell, J., Hanewinkel, M. (2015). How treatment, storm events and changed climate affect productivity of temperate forests in SW Germany. Regional Environmental Change 15:1531-1542

Zlatník, A. (1976). Přehled skupin typů geobiocénů původně lesních a křovinných v ČSR. Zprávy Geografického ústavu ČSAV, 13, s. 55-64.

Zubizarreta-Gerendiain, A., Pukkala, T., Kellomäki, S., Garcia-Gonzalo, J., Ikonen, V-P., Peltola, H. (2015). Effects of climate change on optimised stand management in the boreal forests of central Finland. European Journal of Forest Research 134: 273-280. 